\title{
Importance of light for the formation of algal blooms by Emiliania huxleyi
}

\author{
H. J. Nanninga ${ }^{1}$, T. Tyrrell ${ }^{2, *}$ \\ ${ }^{1}$ Gorlaeus Laboratoria, Rijksuniversiteit Leiden, PO Box 9502, 2300 RA Leiden, The Netherlands \\ ${ }^{2}$ Plymouth Marine Laboratory, Plymouth PL1 3DH, United Kingdom
}

\begin{abstract}
A review of natural bloom and mesocosm data for Emiliania huxleyi suggests a connection between bloom formation, shallow mixed layers and high light intensities. But how does E. huxleyi differ from other algae in its response to light, and what is the cause of the competitive advantage at high light intensities? In this article, $P$-I curves for calcified, naked and de-calcified cultures of $E$. huxleyi are presented. The experimental results show that a lack of photoinhibition in $E$. huxleyi up to at least

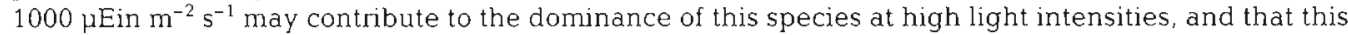
lack of photoinhibition is not due to the presence of reflective coccoliths around the cell.
\end{abstract}

KEY WORDS: Emiliania huxleyi Photosynthesis P-I curves Photoinhibition - Stratification Phytoplankton ecology

\section{INTRODUCTION}

Emiliania huxleyi is a unicellular marine algal species capable of generating vast blooms in the open ocean, with cell concentrations of up to 10000 cells $\mathrm{ml}^{-1}$ (Holligan et al. 1993a), and areal extents of more than $100000 \mathrm{~km}^{2}$ (Brown \& Yoder 1994). These blooms are climatically important due to the emission of dimethylsulphide (DMS) and to the production of organic and inorganic carbon, the latter in the form of large numbers of minute plates of calcium carbonate (coccoliths) (Westbroek et al. 1993). Coccoliths are attached to cells initially, but detach in low numbers during growth (Balch et al. 1993, Bleijswijk et al. 1994b) and in high numbers during the senescent phase of a bloom (Westbroek et al. 1993). Free coccoliths can occur in concentrations of up to $300000 \mathrm{coc}-$ coliths $\mathrm{ml}^{-1}$ in the open ocean (Holligan et al. 1993a).

For the purpose of predicting future environmental impacts of these blooms it is necessary to understand

\footnotetext{
- Addressee tor correspondence. Present address: University of Southampton, Southampton Oceanography Centre, European Way, Southampton SO14 3ZH, United Kingdom

E-mail: t.tyrell@soc.soton.ac.uk
}

the factors causing them; i.e. which biological, chemical and/or physical properties of the water are influential in causing a bloom of Emiliania huxleyi to develop? A survey of literature on these blooms in the field (where a bloom is defined as a cell concentration

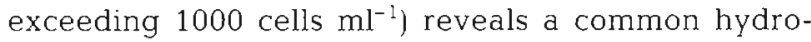
graphic feature associated with all known blooms of $E$. huxleyi: they all occur in highly stratified water where the mixed layer depth is usually $\sim 10$ to $20 \mathrm{~m}$, and is almost always $\leq 30 \mathrm{~m}$. This assertion holds true for blooms in the Gulf of Maine (Townsend et al. 1994), in the North Atlantic (Holligan et al. 1993a, Malin et al. 1993), in the North Sea (Holligan et al. 1993b, Wal et al. 1995), off the Scilly Isles (to the west of the English Channel) (Garcia-Soto et al. 1995), in the Southern Benguela Upwelling (Mitchell-Innes \& Winter 1987), and in the Norwegian fjords (Braarud 1945, Birkenes \& Braarud 1952, Berge 1962, Braarud et al. 1974, Paasche \& Kristiansen 1982, Kristiansen et al. 1994). Stratification occurs together with E. huxleyi in the northern and central North Sea, whereas stratification does not usually occur in the southern North Sea and neither does E. huxleyi (Houghton 1991, Holligan et al. 1993b). However, an exception to the general pattern was encountered in the Celtic and Armorican shelf 
region (Holligan et al. 1983), where E. huxleyi was observed to be present in bloom proportions at depths up to $60 \mathrm{~m}$, albeit with the greatest cell concentrations nearest to the surface. In the Skagerrak, a bloom of $E$. huxleyi (Pingree et al. 1982) was detected in a sub-surface thermocline layer, but the layer was fairly close to the surface (from 10 to $15 \mathrm{~m}$ depth). In another case (Kristiansen et al. 1994), cell concentrations of E. huxleyi were $\geq 1000$ cells $\mathrm{ml}^{-1}$ from the surface down to nearly $20 \mathrm{~m}$, but concentrations were significantly greater at a depth of about $10 \mathrm{~m}$ than at shallower depths. In contrast, similar concentrations of other phytoplankton species can occur in deeper mixed layers with a depth of $75 \mathrm{~m}$ or more (e.g. Braarud 1945; Williams 1974, Fig. 51; Williams \& Hopkins 1976. Fig. 64).

The most likely reason for Emiliania huxleyi being able to out-compete other phytoplankton in stratified waters (surface waters in which the phytoplankton are continually kept very near to the surface) is a competitive advantage at higher light levels. If a non-motile phytoplankton cell is mixed evenly through the depth of the mixed layer, with an equal probability of being at any depth in the mixed layer at any moment in time. then the average light intensity $\left(I_{\hat{\sigma} \mathrm{V}}\right)$ that it will experience is given by

$$
\begin{aligned}
I_{\mathrm{ay}} & =\frac{1}{H} \int_{0}^{H}\left\{I_{0} \cdot \mathrm{e}^{-K_{d^{2}}}\right\} \mathrm{d} z \\
& =\left(\frac{I_{0}}{K_{d} \cdot H}\right)\left\{1.0-\mathrm{e}^{-K_{d} \cdot H}\right\}
\end{aligned}
$$

where $H$ is the depth of the mixed layer, $I_{0}$ is the irradiance intensity immediately below the water surface, $z$ is depth and $K_{d}$ is the vertical attenuation coefficient for the water. This assumes an exponential decay of light with depth which is only an approximation to the real case. A fairly typical oceanic value of $K_{d}$ for photosynthetically active radiation (PAR) is $0.1 \mathrm{~m}^{-1}$ (Kirk 1994), and this value is a reasonable estimate of the mean $K_{d}$ value for the North Atlantic and the seas around northern Europe (Simonot \& Le Treut 1986), where E. huxleyi is most prevalent (Brown \& Yoder 1994). This value of $K_{d}$ relates to changes in the average light intensity with mixed layer depth as shown in. Table 1.

Table 1. Example attenuation of average light in a surface mixed layer $\left(I_{a \mathrm{v}} / I_{0}\right)$ against depth of the mixed layer $(H)$, when the vertical attenuation coefficient $\left(K_{d}\right)$ for the water is

\begin{tabular}{|c|c|c|c|c|c|c|c|c|}
\hline & \multicolumn{8}{|c|}{$H(m)$} \\
\hline & 5 & 10 & 15 & 20 & 30 & 50 & 100 & 200 \\
\hline$I_{\mathrm{av}} / I_{0}(\%)$ & 79 & 63 & 52 & 43 & 32 & 20 & 10 & 5 \\
\hline
\end{tabular}
$0.1 \mathrm{~m}^{-1}$
The average light intensity impinging on the circulated cells is therefore critically dependent on the mixed layer depth. Phytoplankton species which are evolutionarily adapted for high light levels will prosper when mixed layer depths are shallow. Such species would also be more likely to bloom in summer than winter months. Analysis of satellite images in the NE Atlantic south of Iceland shows that Emiliania huxleyi blooms in this region are most common in June and July (S. Groom pers comm.; Brown \& Yoder 1994, Fig. 5A), when mixed layer depths are shallow and surface irradiances are high. Blooms in the Norwegian fjords typically occur during May to August. While other factors (e.g. the nutrient status of the water) must also be important in determining the competitiveness of $E$. huxleyi [because E. huxleyi does not always bloom when the water is stratified and surface illumination is high (e.g. Joint \& Pomroy 1986)], from the close correlation between blooms and stratification it seems as if high light is an essential, although not a sufficient, requirement for bloom formation.

Large concentrations of coccoliths increase the scattering of light in the water (Balch et al. 1991, 1996. Holligan et al. 1993a), and thereby cause an increase in the attenuation of light. At first sight it therefore seems as if the production of coccoliths by Emiliania huxleyi curtails its own success, if the species is indeed high light dependent. It could be suggested that this process is evidence against the 'high light hypothesis' for $E$. huxleyi. There are several counters to this argument though: (1) increased light attenuation also leads to increased stratification and more stable stratification, due to a decreased heating of deeper waters compared to surface waters (Kirk 1988, Sathyendrenath et al. 1991); (2) rapid attenuation of light will starve the thermocline of light, and may prevent the establishment of high concentrations of phytoplankton in the thermocline (P. M. Holligan pers. comm.), which could otherwise intercept the upwards flow of nutrients from below and starve the surface phytoplankton of nutrients (e.g. Taylor et al. 1986); and (3) destruction of its own niche, if indeed that occurs, may be compatible with kin selection (Hamilton 1964).

Alternative explanations of a preference for shallow mixed layers, in terms of temperature, salinity, and nutrient depletion are considered less convincing Emiliania huxleyi is known to be successful across a wide range of temperatures and salinities (Winter et al. 1994). Mesocosm experiments in the Norwegian fjords (Egge \& Heimdal 1994) have shown that E. huxleyi blooms can occur at both low and high concentrations of phosphate and nitrate (see Fig. 1). In these experiments a natural assemblage of phytoplankton was introduced into mesocosm enclosures at the beginning of each experiment, and therefore many species were 

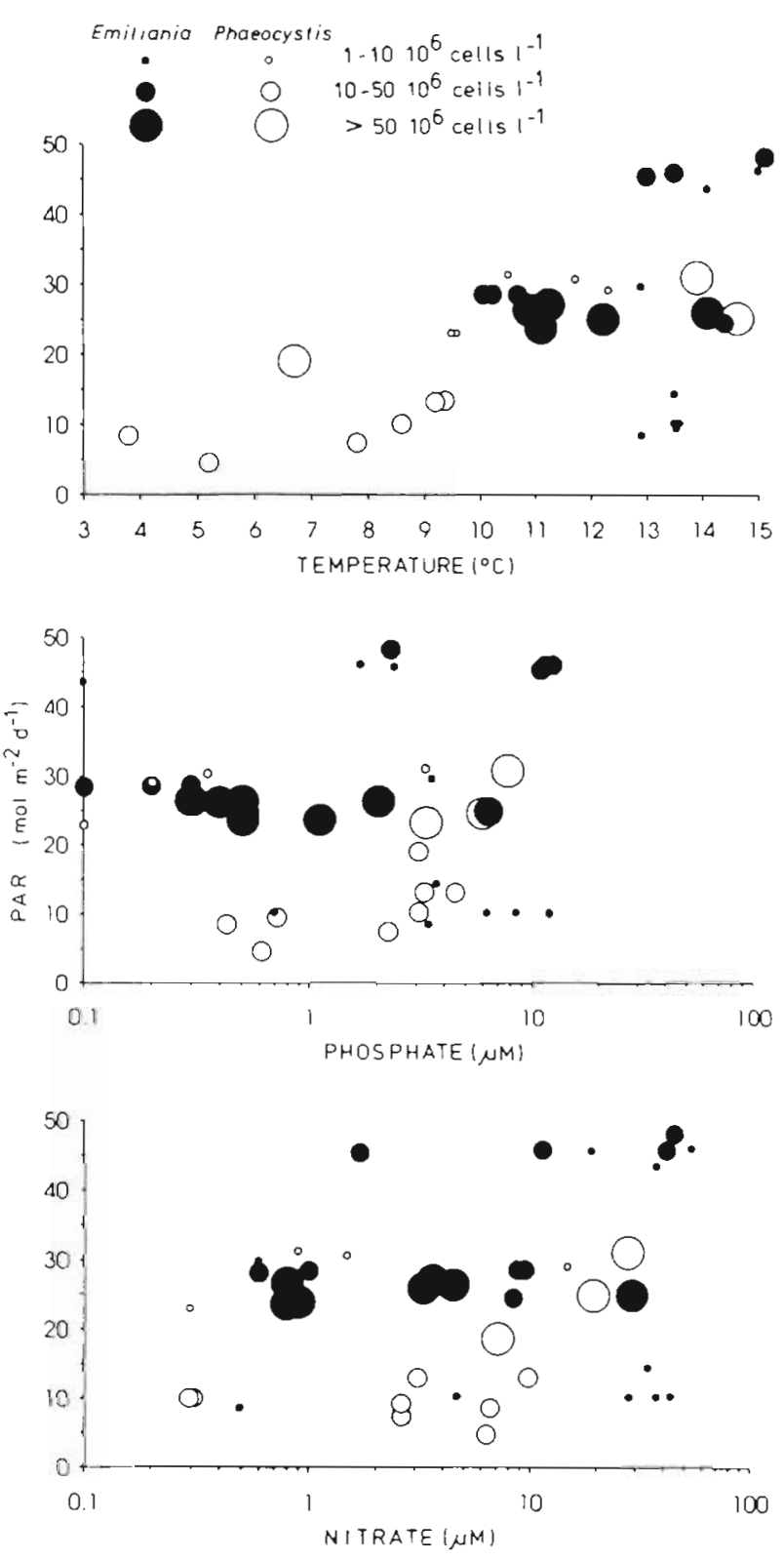

Fig. 1 Populations of Emiliania huxleyi and Phaeocystis sp. (other species not shown) in enclosure experiments durng 1988-1992. Effects of surface irradiance (PAR, mol m $\mathrm{m}^{-2} \mathrm{~d}^{-1}$ ), temperature $(\mathrm{C})$, phosphate $\left(\mu \mathrm{M} \mathrm{kg}^{-1}\right)$ and nitrate $\left(\mu \mathrm{M} \mathrm{kg}^{-1}\right)$ on the dominance of the 2 species are illustrated. The light intensities (in mol m ${ }^{2} \mathrm{~d}^{-1}=$ Ein $\mathrm{m}^{-2} \mathrm{~d}^{-1}$ ) are 5 day averages, calculated by summing hourly averages of instantaneous light values throughout the day to obtain $24 \mathrm{~h}$ totals, and then averaging back over the 5 days before the bloom maximum to calculate a 5 day average (J. K. Egge pers comm.). Assuming $12 \mathrm{~h}$ of daylight per day, 23 Ein $\mathrm{m}^{-2} \mathrm{~d}^{-1}$ is equivalent to $\sim 530 \mu \mathrm{Ein} \mathrm{m}^{-2} \mathrm{~s}^{-1}$

Taken from (Egge \& Heimdal 1994) with permission

present even though only the concentrations of E. huxleyi and Phaeocystis sp. are shown in the figure. The mesocosm experiments also give additional evidence to support a 'high light hypothesis' for E. huxleyi. This line of evidence is not tied to mixed layer depth: the mesocosms had a constant depth of $4 \mathrm{~m}$, which was kept fully stirred throughout the duration of the experiments, and so there were no variations in mixed layer depth to cause variations in light intensity. Fig 1 shows the distribution of $E$. huxleyi population sizes against various environmental parameters (Egge \& Heimdal 1994). In all 3 graphs the most striking correlation is between $E$. huxleyi cell concentration and light intensity, with E. huxleyi only blooming with surface light intensities of greater than $\sim 23$ Ein $\mathrm{m}^{-2} \mathrm{~d}^{-1}(\sim 530 \mu$ Ein $\left.\mathrm{m}^{-2} \mathrm{~s}^{-1}\right)$. There is also a correlation with temperature in Fig. 1. However, light and temperature are not independent in the shallow mesocosms, and it is most likely that the apparent correlation between temperature and $E$. huxleyi success is a side effect of an actual correlation between light and $E$. huxleyi success.

If, as seems to be the case, Emiliania huxleyi has a competitive advantage at high light levels then it is interesting to investigate the underlying reason for this advantage. Two possible explanations are investigated in this paper: (1) that the light intensity at which the maximum photosynthetic rate is reached is increased due to the presence of coccoliths around the exterior of the cells; and (2) that there is an absence of photoinhibition in E. huxleyi at high light levels.

The competitive advantage of Emiliania huxleyi at high light could also be explained by enhanced rates of photoadaptation (Lewis et al. 1984), for instance if $E$. huxleyi is able to adjust its chlorophyll content more rapidly than other species, and fast enough to keep in step with the changing light intensity due to being circulated within the mixed layer. However, photoadaptive differences do not seem to be a plausible explanation of the high light success of $E$. huxleyi in the mesocosm experiments [the mesocosms were of a constant depth and were mixed at a constant rate using a pump (Egge \& Heimdal 1994)], and for this reason photoadaptation will not be considered further here.

\section{METHODS}

Organism and cultivation conditions. An axenic calcifying culture of Emiliania huxleyi clone BOF92 was kindly provided by Prof. E. Paasche (University of Oslo, Norway), who started this clone by single-cell reisolation from isolate $5 / 90 / 25 \mathrm{j}$. Isolate $5 / 90 / 25 \mathrm{j}$ was obtained by J. C. Green from the Atlantic at $48^{\circ} \mathrm{N}$, $17^{\circ} \mathrm{W}$ in May 1990 . From the clone BOF92 a non-calcifying culture was obtained after prolonged rultivation in Eppley medium (Eppley et al. 1967). The calcifying culture was maintained in F/25 medium. F/25 medium. is identical to Eppley medium except for the added 
amounts of $\mathrm{KNO}_{3}$ and $\mathrm{K}_{2} \mathrm{HPO}_{4}$, which are 25 times less for both compounds.

For the photosynthesis experiments cells were used from batch cultures in the exponential phase of growth. The calcifying culture was grown in F/25 and in Eppley medium. The non-calcifying culture was grown in Eppley medium. The batch cultures had a volume of $200 \mathrm{ml}$, were incubated in conical flasks (500 $\mathrm{ml})$, bubbled with humid sterile air $\left(1.4 \mathrm{l} \mathrm{h}^{-1}\right)$, and were kept at $\mathrm{pH} 8.1 \pm$ 0.3 and $18^{\circ} \mathrm{C}$. The conical flasks were placed on a glass plate just above the light source (Philips TL tubes, coolwhite, colour 33). The incident light intensity was $200 \mu \mathrm{Ein} \mathrm{m}^{-2} \mathrm{~s}^{-1}$ for 24 hours per day. The cultures were illuminated continuously to prevent synchronous cell division as the latter may affect the results when photosynthesis rates are related to cell numbers. Prior to the estimation of the photosynthesis rates the 3 cultures were treated as follows. First the $\mathrm{pH}$ was measured. The $\mathrm{pH}$ of the non-calcifying culture (culture $\mathrm{B}$ ) was 8.18 and not modified. The calcified culture in $\mathrm{F} / 25$ medium had a pH of 7.82 and was divided into 2 aliquots. In one aliquot (culture $\mathrm{A}$ ) the $\mathrm{pH}$ was adjusted to 8.2. In the other aliquot (culture C) first the coccoliths were dissolved by lowering the $\mathrm{pH}$ with $\mathrm{HCl}$ to a value of 5.0 for a period of $3 \mathrm{~min}$, followed by readjustment with $\mathrm{NaOH}$ to a $\mathrm{pH}$ of 8.2. The dissolution of all extracellular coccoliths was checked by microscopy and analyses of particulate calcium. The $\mathrm{pH}$ of the calcified culture in Eppley medium (culture D) was 7.98 and adjusted to 8.2. After $\mathrm{pH}$ measurement/modification cultures $A, B, C$ and $D$ were incubated on a gyratory shaker at $18^{\circ} \mathrm{C}$ and a low light intensity $(10$ to $20 \mu \mathrm{Ein}$ $\mathrm{m}^{-2} \mathrm{~s}^{-1}$ ) during 2, 3.5, 5 and $7 \mathrm{~h}$, respectively.

Analyses. Photosynthesis versus irradiance $(P-I)$ curves were monitored using a Clark-type polarographic oxygen electrode according to Dubinsky et al. (1986). In these photosynthesis experiments algae were incubated into a stirred, thermostated PVC chamber and irradiated with a collimated light beam from a tungsten light source which was attenuated to the desired light intensities by a series of nickel screens. Thus the light beam passed successively a nickel screen, a lens of colourless glass, a thin layer of colourless glass, a layer of approximately $1 \mathrm{~cm}$ clear water (the thermostated compartment for cooling), and again a layer of thin colourless glass before entering the compartment with the algae. The intensity of light leaving the compartment with algae, through a thin colourless glass layer at the back side, was measured and used as the value for the light intensity in the algal compartment. To obtain the total oxygen production rates the oxygen consumption rate in the dark (due to algal respiration and oxygen uptake by the electrode) was determined and added to the detected oxygen production rate under light conditions.
Intensities of PAR were measured with a quantum radiometer photometer (Licor, Lincoln, NE, USA, model LI-189, equipped with a quantum sensor type LI-190 SB).

For analyses of particulate calcium, cells and coccoliths were collected on membrane filters (type HVLP, $0.45 \mu \mathrm{m}$ pore size, Millipore Co, Bedford, MA, USA) and rinsed with $1 \mathrm{M}\left(\mathrm{NH}_{4}\right)_{2} \mathrm{CO}_{3}$. Subsequently, the filters were incubated in $20 \mathrm{ml} 0.5 \mathrm{M} \mathrm{HNO}_{3}$ to extract the calcium. The concentration of calcium in the $\mathrm{HNO}_{3}$ solution was determined in an atomic absorption spectrophotometer (Paasche \& Brubak 1994).

The pH of algal cultures was determined with a glass-electrode calibrated with (low ionic) buffer solutions from Merck (Darmstadt, Germany, art. no 12052). The protein contents of cultures were assayed according to Lowry et al. (1951). Cell numbers were determined in a Bürker haemocytometer with a depth of $0.100 \mathrm{~mm}$. To determine the presence of coccoliths at the surface of cells a light microscope with crosspolarised illumination was used.

\section{RESULTS}

Photosynthesis rates were determined for the follow ing cell suspensions of Emiliania huxleyi:

A - untreated calcified cells grown in F/25 medium,

B - untreated non-calcified cells grown in Eppley medium,

$\mathrm{C}$-acid-treated originally calcified cells grown in F/25 medium,

D-untreated calcified cells grown in Eppley medium.

From each of these cultures the cell number, \% of non-calcified cells, protein content and particulate calcium were measured (Table 2). In cultures $A$ and D the calcified cells were usually covered with 1 layer of coccoliths. Furthermore, culture A and especially culture $\mathrm{D}$ contained a large number of free coccoliths. The total amount of coccoliths can roughly be calculated from the average calcium content of a single coccolith which is $0.67 \mathrm{pg}$ (Fagerbakke et al. 1994). Thus 1.4 and $2.6 \mathrm{mg}$ particulate calcium $\mathrm{I}^{-1}$ is equal to $2.1 \times 10^{6}$ and $3.9 \times 10^{6}$ coccoliths $\mathrm{ml}^{-1}$, respectively. Of the acidtreated cells $4 \%$ had 1 or 2 coccoliths. These coccoliths were formed during the $5 \mathrm{~h}$ incubation period between acid treatment and analysis of the photosynthesis rate. The protein content was measured to make it possible to relate the photosynthesis rates to the cellular protein content. From Table 2 it is also evident that the cellular protein content of the cells grown in Eppley medium (B and $D$ ) exceeded that of cells grown in F/25 medium. Therefore, the protein content is not a suitable parameter to relate photosynthesis rates to, when cells cul- 
Table 2. Emiliania huxleyi. Data of the cultures used for photosynthesis measurements: $(A)$ calcified culture on $F / 25$; $(B)$ noncalcified culture on Eppley; (C) decalcified culture on F/25; and (D) calcified culture on Eppley

\begin{tabular}{|ccccc|}
\hline Culture & Cells & $\begin{array}{c}\text { Protein } \\
\text { content } \\
\left(\mathrm{mg} \mathrm{l}^{-1}\right)\end{array}$ & $\begin{array}{c}\text { Cells with } \\
\text { no liths } \\
(\%)\end{array}$ & $\begin{array}{c}\text { Particulate } \\
\text { calcium } \\
\left(\mathrm{mg} \mathrm{l}^{-1}\right)\end{array}$ \\
\hline A & $\left.3.9 \times 10^{-1}\right)$ & 1.7 & 15 & 1.4 \\
B & $7.5 \times 10^{5}$ & 5.2 & 98 & $<0.1$ \\
C & $3.9 \times 10^{5}$ & 1.7 & 96 & $<0.1$ \\
D & $3.8 \times 10^{5}$ & 2.4 & 26 & 2.6 \\
\hline
\end{tabular}

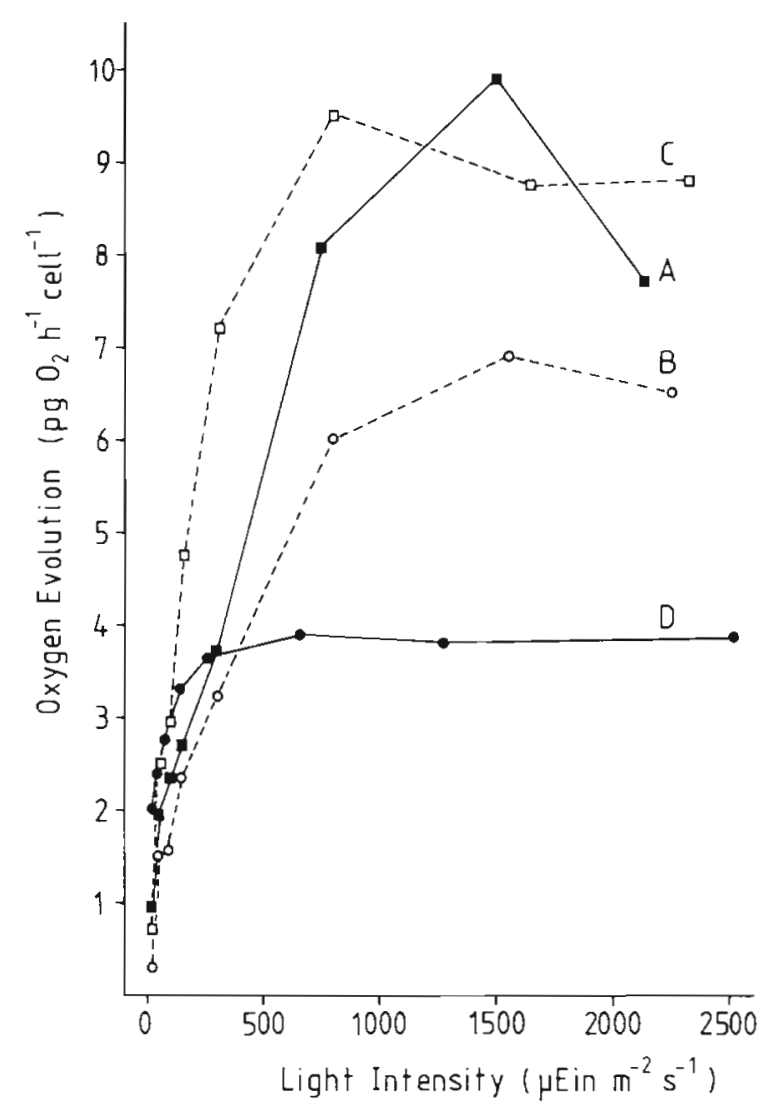

Fig. 2. Photosynthesis (oxygen evolution) versus light intensity for Emiliania huxleyi, with and without coccoliths, and cultivated in Eppley or F/25 medium. ( - A, untreated calcified cells $(\mathrm{F} / 25) ;(0) \mathrm{B}$, untreated non-calcified cells (Eppley); (a) C, acid de-calcified cells (F/25); ( $\bullet$ D, untreated calcified cells (Eppley)

tivated in Eppley medium and in F/25 medium are to be compared.

The P-I curves of the 4 cultures aro shown in Fig. 2. The rate of photosynthesis is measured as an oxygen production rate. For all cultures the maximal rate of photosynthesis is achieved at light intensities above
$500 \mu$ Ein $\mathrm{m}^{-2} \mathrm{~s}^{-1}$ The value of the maximal rate of photosynthesis $\left(P_{\max }\right)$ varies considerably. The value of $P_{\max }$ will depend on several factors such as pigment content, velocity of photochemical electron transport and availability of nutrients (Darley 1982, Dubinsky et al. 1986, Post et al. 1989). Differences in the values of these parameters among the 4 batch cultures may be responsible for the differences in $P_{\max }$ and may also influence the light intensity at which the maximal photosynthetic rate is reached. The 2 cultures in F/25 medium exhibited higher $P_{\max }$ values than the 2 cultures in Eppley medium, but the difference may just have been due to experimental variation. A separate control experiment (results not included) showed that the acid treatment used to decalcify the cells in culture $\mathrm{C}$ had little or no effect on the $P$-I curve obtained. At high light intensities, up to at least 1000 $\mu$ Ein $\mathrm{m}^{-2} \mathrm{~s}^{-1}$, there was no photoinhibition in any of the cultures.

\section{DISCUSSION}

\section{Ecological implications}

As mentioned earlier, one hypothesis to account for the success of Emiliania huxleyi in shallow mixed layers has been related to the light-scattering coccoliths surrounding the cell as this might provide protection from the harmful effect of high light intensities (Lohmann 1913, Braarud et al. 1952, Berge 1962). At high light intensities 2 possible effects of coccoliths can be distinguished. The first involves the light intensity at which $P_{\max }$ is reached $\left(I_{\text {sat }}\right)$. If coccoliths acted as 'protective light screens' then calcified cells would possess a higher $I_{\text {sat }}$. The results just described indicate that this hypothesis is not correct, and confirm a conclusion reached in earlier work that '...coccoliths do not act as protective light screens...' (Paasche \& Klaveness 1970).

The second effect concerns photoinhibition at light intensities beyond $I_{\text {sat }}$. Many species of phytoplankton start to experience light saturation at $\sim 400$ to $500 \mu$ Ein $\mathrm{m}^{-2} \mathrm{~s}^{-1}$ (PAR), and then at higher light intensities the photosynthetic rate declines due to photoinhibition. This decline can be rather drastic, for example with the photosynthetic rate of natural assemblages decreasing to $80 \%$ of $P_{\max }$ at $1000 \mu$ Ein $\mathrm{m}^{-2} \mathrm{~s}^{-1}$, and then to $60 \%$ of $P_{\max }$ at $1500 \mu \mathrm{Ein} \mathrm{m}^{-2} \mathrm{~s}^{-1}$ (Kirk 1994, Fig. 10.1; see also Platt et al. 1980). However, it is apparent from Fig. 2 that photoinhibition does not occur for Emiliania huxleyi until light intensities greater than 1000 to $1500 \mu$ Ein $\mathrm{m}^{-2} \mathrm{~s}^{-1}$ are attained, and even at such high intensities the photoinhibition is not at all pronounced. The importance of photoinhibition in nature is fre- 
quently ignored, but 'The inhibition of photosynthesis at high light intensities must be taken into account in ecological studies, since the intensities typically experienced in the surface layer of natural waters in sunny weather are in the range that can produce photoinhibition' (Kirk 1994, p. 284). In oceanic water a large part of photoinhibition may be attributed to UV light (Kirk 1994, p. 286). Yellow pigments in particular provide protection against UV light and yellow pigments have indeed been detected in E. huxleyi (Kraay et al. 1992). In addition, in situ phytoplankton assemblages have been shown to be more susceptible to photoinhibition at higher latitudes such as $60^{\circ} \mathrm{N}$ (Harrison \& Platt 1986), where blooms of E. huxleyj are most usually found (Brown \& Yoder 1994). The theoretical maximum downwelling light intensity that can be encountered in the field (immediately below the sea-surface from an overhead sun unobscured by cloud and coming through a dry, clean atmosphere) is $-2000 \mu \mathrm{Ein} \mathrm{m}^{-2}$ $\mathrm{s}^{-1}$ (PAR), although in practice values of greater than $1500 \mu$ Ein $\mathrm{m}^{-2} \mathrm{~s}^{-1}$ are only rarely encountered (Kirk 1994). Using Eq. (1), if $I_{0}$ is $1500 \mu$ Ein $\mathrm{m}^{-2} \mathrm{~s}^{-1}$ then the average light intensity in a mixed layer of $15 \mathrm{~m}$ depth $\left(K_{d}=0.1 \mathrm{~m}^{-1}\right)$ is $\sim 780 \mu$ Ein $\mathrm{m}^{-2} \mathrm{~s}^{-1}$. This is compatible with the observation that $E$. huxleyi frequently occurs in mixed layers of $\sim 15 \mathrm{~m}$ depth, and that other phytoplankton start to experience photoinhibition at $\sim 400$ to $500 \mu$ Ein $\mathrm{m}^{-2} \mathrm{~s}^{-1}$. A cruise in 1994 measured in-water scalar light intcnsities of up to $950 \mu \mathrm{Ein} \mathrm{m}^{-2} \mathrm{~s}^{-1}$ in a bloom of $E$. huxleyi in a Norwegian fjord (depth = $2.5 \mathrm{~m}$, E. huxleyi present at $>11000$ cells $\mathrm{ml}^{-1}$ ), and of up to $1140 \mu$ Ein $\mathrm{m}^{-2} \mathrm{~s}^{-1}$ in a bloom of $E$. huxleyi in the North Sea (depth $=2.25 \mathrm{~m}$, E. huxleyi present at $>5000$ cells $\mathrm{ml}^{-1}$ ) (Runar Dallokken unpubl. data). The

Table 3. Emiliania huxleyj. Summary of experimentally derived $P-I$ curves. The columns in the table are (from left to right): (1) reference: used as source of information $(2) I_{\text {cal }}$ : the light intensity at which the maximum $y$-axis value in the $P_{-} I$ curve is first obtained ( $\mu$ Ein $\mathrm{m}^{-2} \mathrm{~s}^{-1}$ ); (3) photoinhibition: whether it was encountered at the light intensities used, and if so then the light intensity at which photoinhibition started to take effect $\left(\mu\right.$ Ein $\left.\mathrm{m}^{-2} \mathrm{~s}^{-1}\right) ;(4) y$-axis: the entity represented by the $y$-axis of the $P$-I curve (growth as no. of doublings $\mathrm{d}^{-1}$, photosynthetic carbon uptake or photosynthetic oxygen evolution); $(5)$ temperature $\left({ }^{\circ} \mathrm{C}\right)$ at which the experiment was carried out; (6) medium, the nutrient medium used (non-std: non-standard); (7) $I_{\text {accl: }}$ : the light intensity to which the cultures were acclimatised before the experiment ( $\mu$ Ein $\mathrm{m}^{-2} \mathrm{~s}^{-1}$ ) (na signifies not applicable for in situ and growth experiments); and (8) strain and place of origin

\begin{tabular}{|c|c|c|c|c|c|c|c|}
\hline Source & $I_{\mathrm{s} a \mathrm{t}}$ & Photoinhibition? & $y$-axis & Temp. & Nutrient & $I_{\text {acd }}$ & $\begin{array}{l}\text { Strain, } \\
\text { place of origin }\end{array}$ \\
\hline Mjaaland (1956) & $150^{a}$ & Yes $\left(400^{\alpha}\right)$ & Growth & 18.0 & 'Soil extract' & na & PML P3 \\
\hline Paasche (1963) & $85^{4}$ & No (up to $144^{\mathrm{d}}$ ) & C uptake & 18.5 & Non-std & $62^{\prime \prime}$ & Oslo fjord \\
\hline $\begin{array}{l}\text { Paasche }(1964) \\
\text { (2 curves) }\end{array}$ & $\begin{array}{l}110^{\mathrm{a}} \\
\text { or } 150^{\mathrm{d}}\end{array}$ & No (up to $360^{\circ}$ ) & C uptake & 18.5 & Non-std & $36^{\mathrm{d}}$ & $\begin{array}{c}\text { F402 } \\
\text { Oslo fjord }\end{array}$ \\
\hline $\begin{array}{l}\text { Paasche }(1967) \\
\text { (4 curves) }\end{array}$ & $240-300^{\mathrm{b}}$ & Some $\left(300^{b}\right)$ & Growth & 21 & Non-std & na & Oslo fjord \\
\hline $\begin{array}{l}\text { Paasche \& Klaveness (1970) } \\
\text { ( } 3 \text { curves) }\end{array}$ & $150^{\mathrm{d}}$ & No (up to $170^{\mathrm{a}}$ ) & C uptake & 21 & Eppley & $230^{\circ}$ & $F$ \\
\hline $\begin{array}{l}\text { Brand \& Guillard (1981) } \\
\text { ( } 2 \text { curves) }\end{array}$ & $320-740^{\mathrm{b}}$ & $\begin{array}{c}\text { No } \\
\left.\text { (up to } 740^{\text {b) }}\right)\end{array}$ & Growth & 21 & $\mathrm{~F} / 2$ & na & $\begin{array}{l}\text { A47 (Brand), } \\
\text { Sargasso Sea }\end{array}$ \\
\hline $\begin{array}{l}\text { Balch et al. (1992) } \\
\text { ( } 2 \text { curves) }\end{array}$ & $\begin{array}{l}700 \text { or } \\
\geq 1600\end{array}$ & No (up to 1600) & C uptake & 15 & $\begin{array}{c}\mathrm{F} / 50+ \\
2 \mu \mathrm{M} \mathrm{NO}{ }_{3}\end{array}$ & 1160 & $\begin{array}{l}\text { Bigelow } 88 \mathrm{E} \\
\text { Gulf of Maine }\end{array}$ \\
\hline Balch et al. $(1992)^{\circ}$ & 900 & No (up to 1600 ) & Cuptake & In situ & In situ & na & $\begin{array}{l}\text { In situ, } 2 \text { m depth. } \\
\text { Gulf of Maine }\end{array}$ \\
\hline $\begin{array}{l}\text { Fernandez et al. }(1993)^{c} \\
\text { (4 curves) }\end{array}$ & 600 & Some $(900)$ & C uptake & $?$ & In situ & na & $\begin{array}{l}\text { In situ } \\
\text { NE Atlantic }\end{array}$ \\
\hline (Holligan et al. (1993a) ${ }^{c}$ & 250 & Yes $(600)$ & Cuptake & $?$ & In situ & na 1 & In situ, NE Atlantic \\
\hline Nimer \& Merrett (1993) & 400 & No (up to 500 ) & C uptake & 15 & Non-std & 50 & Bigelow 88E \\
\hline Nimer \& Merrett (1993) & 400 & No (up to 500 ) & $\mathrm{O}_{2}$ evol. & 15 & Non-std & 50 & Bigelow $88 \mathrm{E}$ \\
\hline $\begin{array}{l}\text { Bleijswi]k et al. (1994a) } \\
\text { ( } 2 \text { curves) }\end{array}$ & 70 & No (up to 150$)$ & Growth & 10 & Non-std & na & $\begin{array}{c}\text { Ch } 24-90, \text { Ch } 25-90 \\
\text { North Sea }\end{array}$ \\
\hline $\begin{array}{l}\text { Nielsen }(1995) \\
\text { (6 curves) }\end{array}$ & 300 & No $\{u p$ to 300$\}$ & $\mathrm{O}_{2}$ evol. & 15 & Non-std & 80 & $\begin{array}{l}\text { Plymouth } \\
\text { B } 92 / 317\end{array}$ \\
\hline $\begin{array}{l}\text { This study } \\
\text { (4 curves) }\end{array}$ & $500-1000$ & $\begin{array}{c}\text { No } \\
\text { (up to } 1000 \text { ) }\end{array}$ & $\mathrm{O}_{2}$ evol. & 18 & $\begin{array}{l}\text { Eppley } \\
\text { or } F / 25\end{array}$ & 200 & $\begin{array}{l}\text { BOF92, } \\
\text { NE Atlantic }\end{array}$ \\
\hline \multicolumn{8}{|c|}{ 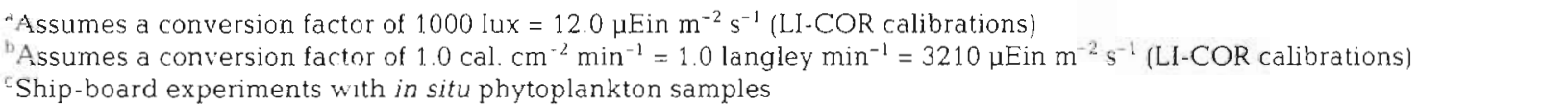 } \\
\hline
\end{tabular}


Charles Darwin cruise no. 60 in 1991 measured inwater downwelling light intensities of up to $935 \mu \mathrm{E}$ in $\mathrm{m}^{-2} \mathrm{~s}^{-1}$ in a bloom of E. huxleyi at $63^{\circ} \mathrm{N}$ in the NE Atlantic (depth $=1 \mathrm{~m}, E$. huxleyi present at $\sim 10000$ cells $\mathrm{ml}^{-1}$ ) [Biogeochemical Ocean Flux Study (BOFS) North Atlantic Dataset CD-ROM].

The results in this paper suggest that Emiliania huxleyi's lack of photoinhibition may be a critical aspect in which it is different from other algae. Coccoliths do not appear to prevent photoinhibition. Nevertheless, the light-scattering properties of coccoliths may be important for the success of $E$. huxleyi. In fact, coccoliths with a diameter of 1 to $2 \mu \mathrm{m}$, as is the case for $E$. huxleyi, appear to provide more scattering per unit weight than smaller or larger coccoliths (Balch et al. 1996), and their size may therefore be the result of an evolutionary selection pressure towards greater scattering. This highly efficient scattering causes a decrease in the penetration of light and heat into the depths of the water (Holligan et al. 1993a), concentrating the heat near the surface of the water (Holligan \& Balch 1991), where it contributes to establishing and maintaining shallow stratification (Simonot et al. 1988). In addition, the rapid attenuation of light could be important for the upwards flow of nutrients as explained in the introduction. Thus, the production of coccoliths may be important in establishing and maintaining the niche of Emiliania huxleyi. This can be compared with e.g. the formation of $\mathrm{H}_{2} \mathrm{~S}$ by sulphate-reducing bacteria in marine sediments. The production of $\mathrm{H}_{2} \mathrm{~S}$ contributes to the maintenance and extension of an anoxic area with a redox potential optimal for growth of sulphatereducing bacteria (Postgate 1984). Another example concerns lactic acid bacteria which can lower the $\mathrm{pH}$ of their environment by the production of lactic acid. As lactic acid bacteria possess a high tolerance for acid, the production of lactic acid enables them to eliminate competition from most other bacteria in environments that are rich in nutrients (Stanier et al. 1976).

\section{Comparisons with previous work}

The high light intensities for photosynthetic saturation in Emiliania huxleyi, as measured in this study, are higher than those obtained in many previous experiments (Table 3 , column 2), but this may in part be due to differences in methodology. One important factor may be the light intensity at which the cultures are grown. In this study this light intensity was $200 \mu$ Ein $\mathrm{m}^{-2} \mathrm{~s}^{-1}$, but in other studies lower light intensities were often applied (column 7). Another factor may be whether growth (cell doublings) or carbon uptake/oxygen evolution were measured (column 4), since the two may not always be coupled (Zevenboom \& Mur 1984,
Banse 1994). The temperature at which the experiments are carried out is also crucial (column 5), as is the nutrient media used (column 6).

The high $I_{\text {sat }}$ values and lack of photoinhibition obtained here are compatible with some of the previous experiments, especially the more recent ones (Table 3, columns 2 and 3). The highest growth rates ever measured for Emiliania huxleyi (2.6 and 2.8 doublings $\mathrm{d}^{-1}$ ) were obtained at high light intensities of 760 and $740 \mu$ Ein $\mathrm{m}^{-2} \mathrm{~s}^{-1}$ (Brand \& Guillard 1981, Brand 1982), higher than the light intensities used in previous growth experiments. The high saturating light intensity indicated by the experiments in this paper is relevant for future laboratory studies of this species. In the past it has been assumed that light values of as little as $100 \mu$ Ein $\mathrm{m}^{-2} \mathrm{~s}^{-1}$ are saturating for E. huxleyi, but this may well not be the case.

\section{CONCLUSIONS}

$P$ - $I$ curves have been derived for calcified, non-calcified and decalcified cultures of Emiliania huxleyi. Comparing these $P$ - $I$ curves revealed that the lack of photoinhibition in E. huxleyi at light intensities up to 1000 or $1500 \mu \mathrm{Ein} \mathrm{m}^{-2} \mathrm{~s}^{-1}$ is not due to reflection of light away from the cells by coccoliths. This absence of photoinhibition may contribute to the dominance of $E$. huxleyi in surface waters of the ocean when mixed layer depths are shallow.

Acknowledgements. The authors are indebted to E. Paasche, P. Westbroek, R. P. Harris, A.H. Taylor, J.K. Egge, J. Aiken, G. F. Moore and P. M. Holligan for valuable discussions and critical reading of the manuscript. L.R. Mur and H. Balke (Amsterdam Univ.) are gratefully acknowledged for making available the equipment to measure photosynthesis rates. This work was funded by the European Commission (contract number MAS2-CT92-0038). This paper is EHUX contribution number 50, and NSG publication number 950613 .

\section{LITERATURE CITED}

Balch WM, Holligan PM, Ackleson SG, Voss KJ (1991) Biological and optical properties of mesoscale coccolithophore blooms in the Gulf of Maine. Limnol Oceanogr 36(4):629-643

Balch WM, Holligan PM, Kilpatrick KA (1992) Calcification, photosynthesis and growth of the bloom-forming coccolithophore, Emiliania huxleyi. Cont Shelf Res 12(12): 1353-1374

Balch WM, Kilpatrick KA, Holligan PM, Cucci T (1993) Coccolith production and detachment by Emiliania huxley (Prymnesiophyceae). J Phycol 29:566-575

Balch WM, Kilpatrick KA, Holligan PM, Harbour DS, Fernández E (1996) The 1991 coccolithophore bloom in the central North Atlantic: II-relating optics to coccolith concentration. Limnol Oceanogr (in press)

Banse K (1994) Uptake of inorganıc carbon and nitrate by 
marine plankton and the Redfield ratio. Global Biogeochem Cycles 8(1):81-84

Berge $G$ (1962) Discoloration of the sea due to Coccolithus huxley 'bloom' Sarsia 6:27-41

Birkenes E, Braarud T (1952) Phytoplankton in the Oslo Fjord during a 'Coccolithus huxleyi-summer'. Avh Nor Viden Akad Oslo 1952/2:1-23

Bleijswijk JDL van, Kempers RS, Veldhuis MJW, Westbroek P (1994a) Cell and growth characteristics of types A and B of Emiliania huxleyi (Prymnesiophyceae) as determined by flow cytometry and chemical analyses. J Phycol 30(2) $230-241$

Bleijswijk JDL van, Kempers RS, Wal P van der, Westbroek P, Egge JK, Lukk T (1994b) Standing stocks of PIC, POC, PON and Emiliania huxleyi coccospheres and liths in seawater enclosures with different phosphate loadings. Sarsia $79(4): 307-318$

Braarud I (1945) A phytoplankton survey of the polluted waters of inner Oslo fjord. Hvalrădets Skr 28:1-142

Braarud T, Gaarder KR, Markali J, Nordli E (1952) Coccolithophorids studied in the electron microscope. Observations on Coccolithus huxleyi and Syracosphaera carterae. Nytt Mag Bot 1:129-134

Braarud T, Föyn Hofsvang B, Hjelmfoss P, Överland AaK (1974) The natural history of the Hardangerfjord. 10. The phytoplankton in 1955-56. The quantitative phytoplankton cycle in the fjord waters and in coastal offshore waters. Sarsia 55:63-98

Brand LE (1982) Genetic variability and spatial patterns of genetic differentiation in the reproductive rates of the marine coccolithophores Emiliania huxleyi and Gephyrocapsa oceanica. Limnol Oceanogr 27(2):236-245

Brand LE, Guillard RRL (1981) The effects of continuous light and light intensity on the reproduction rates of twenty-two species of marine phytoplankton. J Exp Mar Biol Ecol 50: $119-132$

Brown CW, Yoder JA (1994) Coccolithophorid blooms in the global ocean. J Geophys Res 99(C4):7467-7482

Darley WM (1982) Algal biology: a physiological approach. Blackwell Sci Publ, Oxford

Dubinsky Z, Falkowski PG, Wyman K (1986) Light harvesting and utilization by phytoplankton. Plant Cell Physiol $27: 1335-1349$

Egge JK, Heimdal BR (1994) Blooms of phytoplankton including Emiliania huxleyi (Haptophyta). Effects of nutrient supply in different N:P ratios. Sarsia 79:333-348

Eppley RW, Holmes RW, Strickland JDH (1967) Sinking rates of marine phytoplankton measured with a fluorometer. J Exp Mar Biol Ecol 1:191-208

Fagerbakke KM, Heldal M, Norland S, Heimdal BR, Båtvik H (1994) Emiliania huxleyi. Chemical composition and size of coccoliths from enclosure experiments and a Norwegian fjord. Sarsia 79:349-355

Fernández E, Boyd P, Holligan PM. Harbour DS (1993) Production of organic and inorganic carbon within a largescale coccolithophore bloom in the northeast Atlantic Ocean. Mar Ecol Prog Ser 97:271-285

Garcia-Soto C, Fernández E, Pingree RD, Harbour DS (1995) Evolution and structure of a shelf coccolithophore bloom in the Western English Channel. J Plankton Res 17(11): 2011-2036

Hamilton WD (1964) The genetical evolution of social behaviour (I and II). J Theor Biol 12:12-45

Harrison $W G$, Platt $T$ (1986) Photosynthesis-irradiance relationships in polar and temperate phytoplankton populations. Polar Biol 5:153-164

Holligan PM, Balch WM (1991) From the ocean to cells: coc- colithophore optics and biogeochemistry. In: Demers S (ed) Particle analysis in oceanography. (NATO ASI Ser, G27). Springer, Berlin, p 301-324

Holligan PM, Fernández E, Aiken J, Balch WM, Boyd P, Finch M, Groom SB, Maln G, Muller K, Purdie DA, Robinson C, Trees CC, Turner SM, Wal P van der (1993a) A biogeochemical study of the coccolithophore Emiliania huxleyi in the north Atlantic. Global Biogeochem Cycles 7(4): 879-900

Holligan PM, Groom SB, Harbour DS (1993b) What controls the distribution of the coccolithophore, Emiliania huxleyi, in the North Sea? Fish Oceanogr 2(3/4):175-183

Holligan PM, Viollier M, Harbour DS, Camus P, ChampagnePhilippe M (1983) Satellite and ship studies of coccolithophore production along a continental shelf edge. Nature 304:339-342

Houghton SD (1991) Coccolith sedimentation and transport in the North Sea. Mar Geol 99:267-274

Joint IR, Pomroy AJ (1986) Photosynthetic characteristics of nanoplankton and picoplankton from the surface mixed layer. Mar Biol 92:465-474

Kirk JTO (1988) Solar heating of water bodies as influenced by their inherent optical properties. $J$ Geophys Res 93: $10987-10908$

Kirk JTO (1994) Light and photosynthesis in aquatic ecosystems, 2nd edn. Cambridge University Press, Cambridge

Kraay GW, Zapata M, Veldhuis MJW (1992) Separation of chlorophylls $c_{1}, c_{2}$ and $c_{3}$ of marine phytoplankton by reversed-phase-C18-high-performance liquid chromatography. J Phycol 28:708-712

Kristiansen $S$, Thingstad TF, Wal $P$ van der, Farbrot $T$, Skjoldal EF (1994) An Emiliania huxleyi dominated subsurface bloom in Samnangerfjorden, western Norway. Importance of hydrography and nutrients. Sarsia 79 : $357-368$

Lewis MR, Cullen JJ, Platt T (1984) Relationships between vertical mixing and photoadaptation of phytoplankton: similarity criteria. Mar Ecol Prog Ser 15:141-149

Lohmann H (1913) Über Coccolithophoriden. Verh Dt Zool Ges 23:143-164

Lowry OH, Rosebrough NJ, Farr AL, Randall RJ (1951) Protein measurement with the pholin phenol reagent. $J$ Biol Chem 193:265-275

Malin G, Turner SM, Liss PS, Holligan PM, Harbour DS (1993) Dimethyl sulphide and dimethylsulphonioproprionate in the north east Atlantic during the summer coccolithophore bloom. Deep Sea Res I 40:1487-1508

Mitchell-Innes BA, Winter A (1987) Coccolithophores: a major phytoplankton component in mature upwelled waters off the Cape Peninsula, South Africa in March, 1983. Mar Biol 95:25-30

Mjaaland G (1956) Some laboratory experiments on the coccolithophorid Coccolithus huxleyl. Oikos 7(11):251-255

Nielsen MV (1995) Photosynthetic characteristics of the coccolithophorid Emiliania huxleyi (Prymnesiophyceae) exposed to elevated concentrations of dissolved inorganic carbon. J Phycology 31(5):715-719

Nimer NA, Merrett MJ (1993) Calcification rate in Emiliania huxleyi Lohmann in response to light, nitrate and availability of inorganic carbon. New Phytologist 123:673-677

Paasche $E$ (1963) The adaptation of the carbon-14 method for the measurement of coccolith production in Coccolithus huxleyi. Physiol Plant 16:186-200

Paasche E (1964) A tracer study of the inorganic carbon uptake during coccolith formation and photosynthesis in the coccalithophorid Coccolithus huxleyi. Physiol Plant SuppI III:1-82 
Paasche E (1967) Marine plankton algae grown with lightdark cycles. I. Coccolithus huxleyi. Physiol Plant 20: 946-956

Paasche E, Brubak S (1994) Enhanced calcification in the coccolithophorid Emiliania huxleyi (Haptophycaea) under phosphorus limitation. Phycologia 33(5):324-330

Paasche E, Klaveness D (1970) A physiological comparison of coccolith-forming and naked cells of Coccolithus huxleyi. Arch Mikrobiol 73:143-152

Paasche E, Kristiansen S (1982) Ammonium regeneration by microzooplankton in the Oslofjord. Mar Biol 69:55-63

Pingree RD. Holligan PM, Mardell GT, Harris RP (1982) Vertical distribution of plankton in the Skagerrak in relation to doming of the seasonal thermocline. Cont Shelf Res $1(2): 209-219$

Platt T, Gallegos CL, Harison WG (1980) Photoinhibition of photosynthesis in natural assemblages of marine phytoplankton. J Mar Res 38:687-701

Post AF, Zwart G, Sweers JP, Veen A, Rensman D. Heuvel A van der, Mur LR (1989) Chromatic regulation of photosynthesis in cyanobacteria. In: Cohen Y, Rosenberg E (eds) Microbial mats, physiological ecology of benthic microbial communities. Am Soc Microbiol, Washington, p 305-312

Postgate JA (1984) The sulphate reducing bacteria, 2nd edn. Cambridge Univ Press, Cambridge, p 107-123

Sathyendrenath S, Gouveia AD, Shetya SR, Ravindran P, Platt $T$ (1991) Biological control of surface temperature in the Arabian Sea. Nature 349:54-56

Simonot JY, Dollinger E, Le Treut $H$ (1988) Thermodynamicbiological-optical coupling in the oceanic mixed layer. J Geophys Res 93:8193-8202

Simonot JY, Le Treut H (1986) A climatological field of mean optical properties of the world ocean. J Geophys Res 91 (C5):6642-6646

Stanier RY, Adelberg EA, Ingraham JL (1976) General

This article was submitted to the editor microbiology, 4th edn. Prentice-Hall Inc, Englewood Cliffs, NJ

Taylor AH, Harris JRW, Aiken J (1986) The interaction of physical and biological processes in a model of the vertical distribution of phytoplankton under stratification. In: Nihoul JCJ (ed) Marine interfaces ecohydrodynamics. Elsevier Oceanography Series, Vol 42, Amsterdam, p 313-330

Townsend DW, Keller MD, Holligan PM, Ackleson SG, Balch WM (1994) Blooms of the coccolithophore Emiliania huxleyl with respect to hydrography in the Gulf of Maine. Cont Shelf Res 14(9):979-1000

Wal P van der. Kempers ES, Veldhuis MJW (1995) Production and downward flux of organic matter and calcite in the North Sea bloom of the coccolithophore Emiliania huxleyi. Mar Ecol Prog Ser 126:247-265

Westbroek P, Brown CW, Bleijswijk JDL van, Brownlee C, Brummer GJ, Conte M, Egge J, Fernández E, Jordan R, Knappertsbusch M, Stefels J, Veldhuis MJW, Wal P van der, Young J (1993) A model system approach to biological climate forcing: the example of Emiliania huxleyi. Global Planet Change 8:27-46

Williams R (1974) Biological sampling at Ocean Weather Station INDIA $\left(59^{\circ} 00^{\prime} \mathrm{N} 19^{\circ} 00^{\prime} \mathrm{W}\right)$ in 1972. Ann Biol 29:41-44

Williams R, Hopkins CC (1976) Sampling at Ocean Weather Station India $\left(59^{\circ} 00^{\circ} \mathrm{N} 19^{\circ} 00^{\prime} \mathrm{W}\right)$ in 1974. Ann Biol 31: $57-60$

Winter A, Jordan R, Roth P (1994) Biogeography of living coccolithophores in ocean waters. In: Winter A. Siesser WG (eds) Coccolithophores. Cambridge University Press, Cambridge, p 161-177

Zevenboom W. Mur LR (1984) Growth and photosynthesis response of the cyanobacterium Microcystis aeruginosa in relation to photoperiodicity and irradiance. Arch Microbiol 139:232-239

Manuscript first received: July 24, 1995

Revised version accepted: January 9, 1996 